(c) American Dairy Science Association, 2007.

\title{
Within-Herd Heritability Estimated with Daughter-Parent Regression for Yield and Somatic Cell Score
}

\author{
C. D. Dechow ${ }^{* 1}$ and H. D. Normant \\ *Department of Dairy and Animal Science, The Pennsylvania State University, University Park 16802 \\ †Animal Improvement Programs Laboratory, ARS, USDA, Beltsville, MD 20705-2350
}

\begin{abstract}
Estimates of heritability within herd $\left(\mathrm{h}_{\mathrm{WH}}^{2}\right)$ that were generated with daughter-dam regression, daughtersire regression, and REML were compared, and effects of adjusting lactation records for within-herd heritability on genetic evaluations were evaluated. Holstein records for milk, fat, and protein yields and somatic cell score (SCS) from the USDA national database represented herds in the US Northeast, Southeast, Midwest, and West. Four data subsets (457 to 499 herds) were randomly selected, and a large-herd subset included the 15 largest herds from the West and 10 largest herds from other regions. Subset heritabilities for yield and SCS were estimated assuming a regression model that included fixed covariates for effects of dam yield or SCS, sire predicted transmitting ability (PTA) for yield or SCS, herd-year-season of calving, and age within parity. Dam records and sire PTA were nested within herd as random covariates to generate within-herd heritability estimates that were regressed toward mean $\mathrm{h}_{\mathrm{WH}}^{2}$ for the random subset. Heritabilities were estimated with REML using sire models (REML ${ }_{\text {SIRE }}$ ), sire-maternal grandsire models (REML $L_{M G S}$ ), and animal models (RE$\mathrm{ML}_{\mathrm{ANIM}}$ ) for each herd individually in the large-herd subset. Phenotypic variance for each herd was estimated from herd residual variance after adjusting for effects of year-season and age within parity. Deviations from herd-year-season mean were standardized to constant genetic variance across herds, and records were weighted according to estimated error variance to accommodate $\mathrm{h}_{\mathrm{WH}}^{2}$ when estimating breeding values. Mean $\mathrm{h}_{\mathrm{WH}}^{2}$ tended to be higher with daughter-dam regression ( 0.35 for milk yield) than with daughter-sire regression ( 0.24 for milk yield). Heritability estimates varied widely across herds (0.04 to 0.67 for milk yield estimated with daughter-dam regression), and $h_{\mathrm{WH}}^{2}$ deviated from subset means more for large herds than for small herds. Correlation with $\mathrm{REML}_{\mathrm{ANIM}} \mathrm{h}_{\mathrm{WH}}^{2}$ was 0.68
\end{abstract}

Received December 30, 2005.

Accepted August 9, 2006.

${ }^{1}$ Corresponding author: cdechow@psu.edu for daughter-dam and was 0.45 for daughter-sire $\mathrm{h}_{\mathrm{WH}}^{2}$ for milk yield. The correlation between daughtersire $\mathrm{h}_{\mathrm{WH}}^{2}$ and $\mathrm{REML} \mathrm{MGS}_{\mathrm{MG}}$ was greater than the correlation between daughter-dam $\mathrm{h}_{\mathrm{WH}}^{2}$ and $\mathrm{REML}_{\mathrm{MGS}}$. Data adjustments had a minimal impact on breeding value bias. Within-herd heritability can be estimated rapidly using regression techniques with moderate accuracy, but adjusting lactation records for $\mathrm{h}_{\mathrm{WH}}^{2}$ resulted in only a small improvement in the accuracy of genetic evaluations.

Key words: heritability, daughter-dam regression, daughter-sire regression

\section{INTRODUCTION}

Genetic evaluations for most traits assume that heritability is constant across herds within a breed. However, management and environmental factors that vary across herds could result in different heritabilities. In addition, the accuracy of records that contribute to genetic evaluations varies across herds. Inaccurate parent identification reduces heritability estimates and PTA accuracy (Gelderman et al., 1986; Banos et al., 2001). Herd characteristics that may not directly influence data accuracy, such as larger herd size or higher maximum monthly temperature, also were associated with lower heritability estimates in an across-country study (Zwald et al., 2003). The herd characteristics that have received the most attention for their relationship to heritability are mean yield and yield variance. Heritability estimates typically increase as mean herd yield and herd phenotypic variance increase (Lofgren et al., 1985; Vinson, 1987; Van Tassell et al., 1999).

Herd-year heritability for yield is assumed to increase when the standard deviation (SD) for phenotype increases (Wiggans and VanRaden, 1991) and is constrained to range from 0.25 to 0.35 in the US genetic evaluation of Holsteins (Van Tassell et al., 1999). Within-herd heritability is accounted for by standardizing yield to a constant genetic SD prior to generating EBV and weighted by the ratio of base error variance to herd error variance while generating EBV (Wiggans and VanRaden, 1991). Final type scores are standardized to a constant phenotypic variance to account for 
reduced variance as the herd mean type score increases, but herd heritability is not assumed to vary (Weigel and Lawlor, 1994).

Efforts to standardize records to constant genetic or phenotypic variance have resulted in improvements in the accuracy of sire PTA (Wiggans and VanRaden, 1991; Powell et al., 1994; van der Werf et al., 1994; Weigel and Lawlor, 1994). The use of direct estimates of within-herd heritability $\left(\mathbf{h}_{\mathbf{W H}}^{2}\right)$ may be more precise than heritability inferred from herd variance. Estimating a separate heritability for a large number of herds on a routine basis using REML is not feasible, and heritability estimates are not accurate for small data sets (Falconer and Mackay, 1996). Alternatively, regression techniques could be used that are computationally feasible. Within-herd heritability could be regressed toward the mean for small herds that lack sufficient data to estimate $\mathrm{h}_{\mathrm{WH}}^{2}$ accurately. Daughter-dam regression and paternal half-sibling correlations can be used to derive heritability (Falconer and Mackay, 1996), and both are based on sources of pedigree information that are recorded to some extent in nearly all herds.

Most herds have too few paternal half-siblings to estimate heritability directly from half-sibling correlations. Regressions on sire PTA, which are generated primarily with half-sibling records, give some indication of genetic variation and could be used to infer herd heritability. In a comparison of grazing and confinement herds in the United States, genetic variance in the grazing herds was estimated to be 62 to $87 \%$ lower than in confinement herds (Kearney et al., 2004). Regression of mature-equivalent (ME) milk on sire PTA for milk was correspondingly lower in grazing herds (0.78) than in the confinement herds (0.99).

The objectives of this study were 1) to estimate $\mathrm{h}_{\mathrm{WH}}^{2}$ rapidly and accurately using regression techniques, 2) to evaluate $h_{\mathrm{WH}}^{2}$ differences and factors that contribute to those differences, and 3) to evaluate the effect on genetic evaluation accuracy when using $\mathrm{h}_{\mathrm{WH}}^{2}$ to standardize records across herds to constant genetic variance and to weight records according to estimated error variance.

\section{MATERIALS AND METHODS}

\section{Data}

Mature-equivalent milk, fat, and protein yields and mean SCS records from first- through fifth-parity Holstein cows that had calved between January 1997 and June 2004 were obtained from the USDA national lactation database for selected states that represented 4 regions: West (California), Midwest (Wisconsin), Northeast (New York and Pennsylvania), and Southeast (Ala- bama, Arkansas, Florida, Georgia, Louisiana, Mississippi, North Carolina, Oklahoma, South Carolina, Tennessee, and Texas). Four data subsets were created to provide replication across multiple samples and to analyze a large number of herds within computational limits. The 4 subsets were created by randomly selecting herds across regions. A fifth subset was created by selecting the largest herds from the 4 original subsets: the 10 largest herds from the Northeast, Southeast, and Midwest regions and the 15 largest herds from the West. Herd size in the large-herd subset ranged from 1,076 lactation records from 671 cows to 19,856 lactation records from 9,497 cows.

All cows were required to have either a dam from the same herd or a sire with an official genetic evaluation. Dams were required to be from the same herd because heritability estimates were intended to reflect $\mathrm{h}_{\mathrm{WH}}^{2}$ and not the general population heritability. A minimum of $4,500 \mathrm{~kg}$ of $\mathrm{ME}$ milk was required, and records from second and later parities were retained only if a firstparity record was available. Contemporary groups were similar to those used in national genetic evaluations. Herd-year-seasons of calving were 6 bimonthly calving seasons. For herd-year-seasons with $<5$ cows, seasons were expanded to 4-mo intervals. Herd-year was substituted for herd-year-season if $<5$ cows were in the herdyear-season after expanding the season length; herdyears with $<5$ cows were excluded. Of the original records across subsets, $24 \%$ were removed because of additional data edits.

The numbers of records, cows, daughter-dam pairs, sires, and herds for each data subset are shown in Table 1. Data subsets ranged from 206,766 to 290,544 records. Percentages of cows with a dam record from the same herd ranged from 55 to 59\% (large-herd subset). The mean number of records by region ranged from 51,469 (Midwest) to 72,306 (West).

\section{REML Estimates for $h_{W H}^{2}$}

Restricted maximum likelihood heritability estimates were generated for the 45 large herds by using sire models (REML $\mathbf{S I R E}_{\mathbf{S I}}$ ), sire-maternal grandsire models $\left(\mathbf{R E M L}_{\mathbf{M G S}}\right)$, and animal models (REML $\left.\mathbf{A N I M}_{\mathbf{A N}}\right)$. Heritability estimates were generated for each herd individually, resulting in 135 individual herd analyses (45 from each model) for each trait. Heritability for each herd was estimated by AS-REML (Gilmour et al., 2002) with the following model:

$$
\mathbf{y}=\mathbf{X B}+\mathbf{Z u}+\mathbf{W p}+\mathbf{e},
$$

where $\mathbf{y}$ is a vector of ME milk, fat, or protein yields or SCS, $\mathbf{X}$ is the incidence matrix for fixed effects, $\mathbf{B}$ is 
Table 1. Overall numbers of records, cows, daughter-dam pairs, sires, and herds and regional numbers of records by data subset

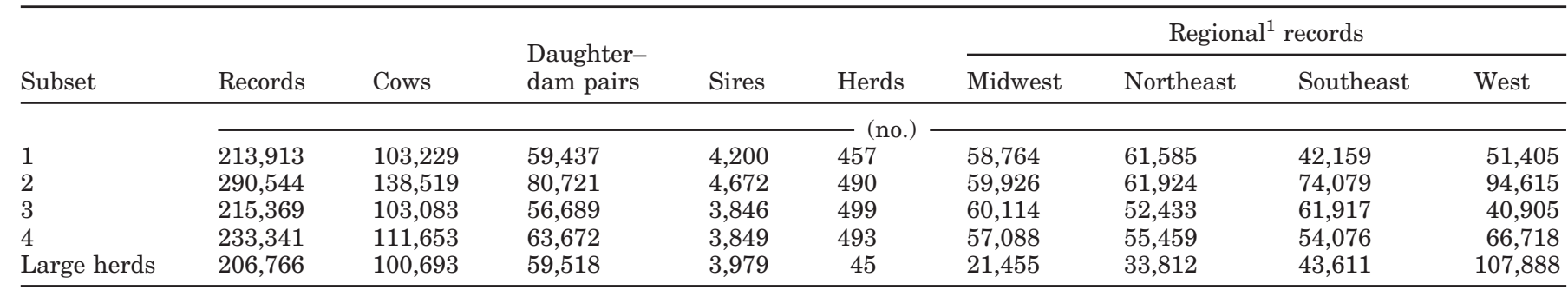

${ }^{1}$ West $=$ California Midwest $=$ Wisconsin Northeast $=$ New York and Pennsylvania and Southeast = Alabama, Arkansas, Florida, Georgia, Louisiana, Mississippi, North Carolina, Oklahoma, South Carolina, Tennessee, and Texas.

a vector of fixed effects (age within parity and yearseason of calving), $\mathbf{Z}$ is the incidence matrix for additive pedigree (animal, sire, or sire + MGS), $\mathbf{u}$ is a vector of random pedigree effects, $\mathbf{W}$ is the incidence matrix for permanent environmental effects, $\mathbf{p}$ is a vector of random permanent environmental effects, and $\mathbf{e}$ is a vector of random residuals.

\section{Daughter-Dam and Daughter-Sire Estimates for $h_{\mathrm{WH}}^{2}$}

The $\mathrm{h}_{\mathrm{WH}}^{2}$ for milk, fat, and protein yields and SCS were estimated with daughter-dam and daughter-sire regressions. Dam records were the residuals from the following model:

$$
\mathrm{y}_{\mathrm{ij}}=\mathrm{b}_{\mathrm{i}} \mathrm{A}_{\mathrm{i}}+\mathrm{H}_{\mathrm{j}}+\mathrm{e}_{\mathrm{ij}}
$$

where y is ME milk, fat, or protein yield or SCS for parity $i$ of cow in year-season $j ; b_{i}$ is the coefficient for fixed regression on age nested within parity (A), $\mathrm{H}$ is a fixed effect of year-season, and e is the effect of the random residual. The analysis was applied to each herd individually, which was computationally feasible and easily accommodated with the MIXED procedure of SAS (SAS Institute, 2000). Daughter ME milk, fat, and protein yields and SCS were then regressed on the corresponding dam record. Daughter-dam and daughtersire regressions were conducted simultaneously. This procedure required no missing values to make use of all available dam records when sire PTA was missing, or to make use of sire PTA when dam records were missing. Sire PTA and dam records were averaged for each herd-year-season and included for cows with missing values.

Regression models to estimate $\mathrm{h}_{\mathrm{WH}}^{2}$ included fixed regression coefficients to estimate mean heritability for each data subset. An additional random coefficient nested within herd allowed the calculation of $\mathrm{h}_{\mathrm{WH}}^{2}$ estimates that were regressed toward the subset mean. The model for estimating heritabilities in AS-REML (Gilmour et al., 2002) was

$$
\begin{aligned}
\mathrm{y}_{\mathrm{ijk} l}=\mathrm{b}_{\mathrm{i}} \mathrm{A}_{\mathrm{i}} & +\mathrm{H}_{\mathrm{j}}+\mathrm{b}_{2} \mathrm{D}+\mathrm{b}_{3} \mathrm{~S}+\mathrm{b}_{4}\left(\mathrm{~S} \times \mathrm{SD}_{\mathrm{k}}\right) \\
& +\mathrm{b}_{1 l} \mathrm{~F}_{l}+\mathrm{b}_{2 l} \mathrm{G}_{l}+\mathrm{e}_{\mathrm{ijk} l}
\end{aligned}
$$

where y is ME milk, fat, or protein yield or SCS for parity $\mathrm{i}$ of cow in herd $l$, herd-year $\mathrm{k}$, and herd-yearseason $j$; $b_{i}$ is a coefficient for fixed regression on age (A) nested within parity i; $\mathrm{H}$ is a fixed effect of herdyear-season; $b_{2}$ is a coefficient for fixed regression on dam record (D); $b_{3}$ is a coefficient for fixed regression on sire PTA (S); $b_{4}$ is a coefficient for fixed regression on the interaction between sire PTA and herd-year SD for yield or $\mathrm{SCS} ; \mathrm{b}_{1 l}$ is a coefficient for random regression on dam record nested within herd $(\mathrm{F}) ; \mathrm{b}_{2 l}$ is a coefficient for random regression on sire PTA nested within herd $(\mathrm{G})$; and e is an effect of the random residual. An analysis of milk yield without regression on fixed effects $\left[b_{2} D\right.$, $\mathrm{b}_{3} \mathrm{~S}$, and $\left.\mathrm{b}_{4}\left(\mathrm{~S} \times \mathrm{SD}_{\mathrm{k}}\right)\right]$ was also performed to determine the effect of deviating from an overall fixed regression coefficient.

Herd phenotypic variance estimates (and herd-year SD) were derived using residual variance for each herd from model [2]. Residual variances from current, previous, and subsequent herd-years and mean residual variance for the data subset were weighted according to the procedures of Wiggans and VanRaden (1991) to estimate herd-year phenotypic variance that was regressed toward the subset mean with the following formula:

$$
\begin{gathered}
\hat{\sigma}_{H Y}^{2}= \\
\frac{20 \times \sigma_{S}^{2}+N_{H Y} \times \sigma_{H Y}^{2}+\frac{1}{2} N_{H Y-1} \times \sigma_{H Y-1}^{2}+\frac{1}{2} N_{H Y+1} \times \sigma_{H Y+1}^{2}}{20+N_{H Y}+\frac{1}{2} N_{H Y-1}+\frac{1}{2} N_{H Y+1}}
\end{gathered}
$$

where $\hat{\sigma}_{H Y}^{2}$ is the phenotypic variance estimate for the current herd-year, $\sigma_{S}^{2}$ is the average residual variance $\left(e_{i j}\right)$ from model [2] for $\mathrm{j}$ herd-year seasons in the current year, $\sigma_{H Y}^{2}$ is $\mathrm{e}_{\mathrm{ij}}$ in the current year, $\sigma_{H Y-1}^{2}$ is $\mathrm{e}_{\mathrm{ij}}$ for the previous year, $\sigma_{H Y+1}^{2}$ is $\mathrm{e}_{\mathrm{ij}}$ in the subsequent year, $N_{H Y}$ 
are the degrees of freedom for the current year, $N_{H Y-1}$ are the degrees of freedom for the previous year, and $N_{H Y+1}$ are the degrees of freedom for the subsequent year. The degrees of freedom were assumed to be the number of records minus 1 . Weights derived from the inverse of standard errors could replace degrees of freedom, but that approach was not examined in this study.

The $\mathrm{h}_{\mathrm{WH}}^{2}$ from the daughter-dam regression was $2\left(\mathrm{~b}_{2}\right.$ $\left.+b_{l l}\right)$. To estimate $h_{\mathrm{WH}}^{2}$ from the daughter-sire regression, the additive genetic SD for the herd was first assumed to be

$$
\left[\mathrm{b}_{3}+\mathrm{b}_{4}\left(\mathrm{SD}_{\mathrm{k}}\right)+\mathrm{b}_{2 l}\right] \mathrm{SD}_{\mathrm{US}}
$$

where $\mathrm{SD}_{\mathrm{US}}$ is the genetic $\mathrm{SD}$ assumed for USDA-DHIA Holstein genetic evaluations (755 kg for ME milk). Thus, a herd with

$$
\mathrm{b}_{3}+\mathrm{b}_{4} \mathrm{SD}_{\mathrm{k}}+\mathrm{b}_{6}=2
$$

was assumed to have twice the genetic SD of the general population. The $\mathrm{h}_{\mathrm{WH}}^{2}$ from daughter-sire regression was herd additive genetic variance divided by $\hat{\sigma}_{H Y}^{2}$. Because $\hat{\sigma}_{H Y}^{2}$ was used in the analysis of daughter-sire regressions, $\mathrm{h}_{\mathrm{WH}}^{2}$ heritability could vary each year for daughter-sire regression. Midparent $\mathrm{h}_{\mathrm{WH}}^{2}$ was the mean of $\mathrm{h}_{\mathrm{WH}}^{2}$ from daughter-dam and daughter-sire regressions.

The relationship between $\mathrm{h}_{\mathrm{WH}}^{2}$ and herd parameters that could be indicators of $\mathrm{h}_{\mathrm{WH}}^{2}$ was assessed with a multiple regression model in the GLM procedure of SAS (SAS Institute, 2000) with $\mathrm{h}_{\mathrm{WH}}^{2}$ as the dependent variable. Independent variables included region (California, Northeast, Southeast, Wisconsin), average number of first-lactation animals calving per year within region, percentage of cows identified by a registration number, average age at first calving, herd average yield or SCS, and herd phenotypic SD of yield or SCS.

\section{Data Adjustment}

Animal-model EBV were generated with BLUPF90 (Misztal, 2004) with and without adjustment for $\mathrm{h}_{\mathrm{WH}}^{2}$ with methods similar to those of Wiggans and VanRaden (1991). The model to estimate breeding values was similar to model [1]. The only difference was that EBV were generated with records from all herds in a subset, so year-season was replaced with herd-year-season and only animal was considered as a pedigree effect.

Records were standardized to constant genetic variance prior to estimation of breeding values, whereas error variance differences among herds were accommo- dated by weighting records simultaneously with estimation of breeding values. Genetic and permanent environmental variances were identical to those used in national genetic evaluations, which are based on assumed heritabilities of 0.30 and repeatabilities 0.55 for yield traits (Van Tassell et al., 1999) and 0.10 and 0.35, respectively, for SCS (Schutz, 1994). Estimates of $\mathrm{h}_{\mathrm{WH}}^{2}$ for yield were constrained to a range between 0.10 and 0.50 before adjusting for $\mathrm{h}_{\mathrm{WH}}^{2}$. Heritability constraints were made to prevent overextrapolation and because negative weights would have been obtained if herd heritability had been allowed to be greater than the assumed repeatability.

Daughter milk, fat, and protein yields and SCS were deviated from herd-year-season means for those traits. Resulting deviations were multiplied by the ratio of $\mathrm{SD}_{\mathrm{US}}$ to herd additive genetic SD. Changes in error variance were accommodated by weighting records with the ratio of error variance for national genetic evaluations to estimated error variance after adjusting for herd additive genetic SD (Wiggans and VanRaden, 1991).

\section{Tests of Data Adjustments}

Methods derived by van der Werf et al. (1994) and Reverter et al. (1994) to detect bias in genetic parameter estimates were adapted to determine the effect of data adjustments. The methods rely on comparisons of EBV in subsequent genetic evaluations. For each data subset, EBV were first generated only with records from cows calving in 2000 and earlier (EBV2000) and second with the complete data subset (EBV2004). Data adjustments for EBV2000 were based on $\mathrm{h}_{\mathrm{WH}}^{2}$ generated with records from calvings in 2000 and earlier. The EBV from sires that entered a young sire program between July 1995 and July 1997 were selected to evaluate the effects of data adjustments. Sires were required to have 1) daughters that calved in multiple herds by 2000 or earlier, 2) daughters in at least one additional herd after 2000,3) a reliability for EBV2000 of at least 50\% for yield or $35 \%$ for SCS, and 4) a reliability for EBV2004 of at least $80 \%$ for yield or $60 \%$ for SCS. The EBV2000 for sires that entered AI in this time period would be derived from first-crop daughters, whereas EBV2004 would include second-crop daughters. The effect of data adjustments on bias attributable to factors such as preferential treatment of daughters sired by elite proven bulls can then be detected.

The EBV2004 were regressed on EBV2000, and fluctuations in EBV were compared across subsequent genetic evaluations to determine the effects of data adjustments. van der Werf et al. (1994) obtained an observed 
Table 2. Mean within-herd $\mathrm{h}^{2}$ (diagonal) for milk yield for daughter-dam and daughter-sire regressions, midparent, ${ }^{1} \mathrm{REML}_{\mathrm{SIRE}},{ }^{2} \mathrm{REML}_{\mathrm{MGS}}{ }^{3}$ and $\mathrm{REML}_{\mathrm{ANIM}}{ }^{4}$ and correlations (above diagonal) among $\mathrm{h}^{2}$ for 45 large herds

\begin{tabular}{|c|c|c|c|c|c|c|}
\hline Item & $\begin{array}{l}\text { Daughter- } \\
\text { dam }\end{array}$ & $\begin{array}{l}\text { Daughter- } \\
\text { sire }\end{array}$ & Midparent & $\mathrm{REML}_{\text {SIRE }}$ & $\mathrm{REML}_{\mathrm{MGS}}$ & $\mathrm{REML}_{\mathrm{ANIM}}$ \\
\hline Daughter-dam & 0.32 & 0.45 & 0.74 & 0.31 & 0.42 & 0.68 \\
\hline Daughter-sire & & 0.27 & 0.93 & 0.43 & 0.56 & 0.45 \\
\hline Midparent & & & 0.29 & 0.44 & 0.59 & 0.61 \\
\hline REML $_{\text {SIRE }}$ & & & & 0.19 & 0.94 & 0.78 \\
\hline $\mathrm{REML}_{\mathrm{MGS}}$ & & & & & 0.20 & 0.86 \\
\hline REML $_{\text {ANIM }}$ & & & & & & 0.21 \\
\hline
\end{tabular}

${ }^{1}$ Mean of daughter-dam and daughter-sire $\mathrm{h}_{\mathrm{WH}}^{2}$.

${ }^{2}$ Heritability estimates derived with sire models in REML.

${ }^{3}$ Heritability estimates derived with sire-maternal grandsire models in REML.

${ }^{4}$ Heritability estimates derived with animal models in REML.

genetic variance based on EBV fluctuation with the following formula:

$$
\hat{\sigma}_{a}^{2}=\frac{\sum\left(E B V_{2004 i}-E B V_{2000 i}\right)^{2} / \Delta r_{i}^{2}}{n},
$$

where $\hat{\sigma}_{a}^{2}$ is observed genetic variance based on fluctuations in genetic evaluations, $\mathrm{EBV}_{2004 \mathrm{i}}$ is EBV2004 for sire i, $\mathrm{EBV}_{2000 \mathrm{i}}$ is $\mathrm{EBV} 2000$ for sire $\mathrm{i}, \Delta r_{i}^{2}$ is the change in reliability from EBV2000 to EBV2004 for sire i, and $\mathrm{n}$ is the number of sires. The ratio of $\hat{\sigma}_{a}^{2}$ to the genetic variance used to derive EBV indicates whether fluctuations were larger than expected relative to the amount of information gained in subsequent evaluations, whereas regression of EBV2004 on EBV2000 would be expected to be 1 in the absence of any bias (Reverter et al., 1994). The significance of differences in fluctuations was determined by comparing $\hat{\sigma}_{a}^{2}$ before and after data adjustments with a 2 -tailed paired $t$-test.

\section{RESULTS}

\section{Large Herd $h_{W H}^{2}$}

Means and correlations among daughter-dam $\mathrm{h}_{\mathrm{WH}}^{2}$, daughter-sire $h_{\mathrm{WH}}^{2}$, midparent $\mathrm{h}_{\mathrm{WH}}^{2}, R E \mathrm{RL}_{\mathrm{SIRE}} \mathrm{h}_{\mathrm{WH}}^{2}$, $\mathrm{REML}_{\mathrm{MGS}} \mathrm{h}_{\mathrm{WH}}^{2}$, and REML $\mathrm{ANIM}_{\mathrm{WH}} \mathrm{h}_{\mathrm{WH}}^{2}$ for milk yield are shown in Table 2 for the large-herd subset. Mean $\mathrm{h}_{\mathrm{WH}}^{2}$ was highest when estimated with daughter-dam regression (0.32) and lowest when estimated with RE$\mathrm{ML}_{\mathrm{SIRE}}$ (0.19). Heritability estimates ranged from 0.04 to 0.45 for daughter-dam $\mathrm{h}_{\mathrm{WH}}^{2}, 0.01$ to 0.64 for daughter-sire $\mathrm{h}_{\mathrm{WH}}^{2}$, and 0.04 to 0.36 for $\mathrm{REML}_{\mathrm{ANIM}} \mathrm{h}_{\mathrm{WH}}^{2}$. The $\mathrm{h}_{\mathrm{WH}}^{2}$ estimated with $\mathrm{REML}_{\mathrm{ANIM}}$ had standard errors ranging from 0.02 to 0.08 . Daughter-sire $\mathrm{h}_{\mathrm{WH}}^{2}$ could change by year within herd because the estimation of daughter-sire $\mathrm{h}_{\mathrm{WH}}^{2}$ was dependent on herd-year SD. The intraclass correlation for daughter-sire $\mathrm{h}_{\mathrm{WH}}^{2}$ ranged from 0.91 (fat yield) and 0.95 (milk yield), indicating that daughter-sire $h_{\mathrm{WH}}^{2}$ varied little across years within the same herd. Thus, daughter-sire $\mathrm{h}_{\mathrm{WH}}^{2}$ were averaged across years for each herd when generating the correlations shown in Table 2 and in subsequent tables. Correlations among heritability estimates ranged from 0.31 between daughter-dam and REML $\mathrm{SIRE}_{\mathrm{WH}}^{2}$ to 0.94 between REML $L_{\text {SIRE }}$ and REML $L_{M G S} h_{\mathrm{WH}}^{2}$.

Average $\mathrm{h}_{\mathrm{WH}}^{2}$ for fat and protein yields and SCS followed trends similar to those for milk yield (Table 3 ). Mean $\mathrm{h}_{\mathrm{WH}}^{2}$ for fat yield (0.33) and for SCS (0.21) were highest when estimated with daughter-dam regression and highest for protein yield (0.30) with daughter-sire regression. Mean $\mathrm{h}_{\mathrm{WH}}^{2}$ was lowest for protein (0.19) and fat (0.16) yields when estimated with REML ${ }_{\mathrm{SIRE}}$ and lowest for SCS (0.03) with daughter-sire regression.

Correlations among daughter-dam, daughter-sire, and midparent $\mathrm{h}_{\mathrm{WH}}^{2}$ with REML heritability estimates are given in Table 4. Daughter-dam $\mathrm{h}_{\mathrm{WH}}^{2}$ was most strongly correlated with $\mathrm{REML}_{\mathrm{ANIM}}$ (range 0.50 to 0.68 ), whereas daughter-sire $\mathrm{h}_{\mathrm{WH}}^{2}$ was most strongly correlated with REML $L_{M G S}$ (range 0.27 to 0.67 ). For all traits, correlations of daughter-sire $\mathrm{h}_{\mathrm{WH}}^{2}$ with REML $\mathrm{SIRE}_{\mathrm{S}}$ and $\mathrm{REML}_{\mathrm{MGS}}$ were greater than correlations between daughter-dam $h_{\mathrm{WH}}^{2}$ and $\mathrm{REML}_{\mathrm{SIRE}}$ or REML $\mathrm{RGS}_{\mathrm{MGS}}$. Daughter-dam $\mathrm{h}_{\mathrm{WH}}^{2}$ was also more strongly correlated with REML $L_{A N I M} h_{W H}^{2}$ than was daughter-sire $h_{W H}^{2}$ for each trait. Correlations among REML $\mathrm{h}_{\mathrm{WH}}^{2}$ for SCS with daughter-dam and daughter-sire $\mathrm{h}_{\mathrm{WH}}^{2}$ were generally not significantly different from 0 .

Correlations among $\mathrm{h}_{\mathrm{WH}}^{2}$ for yield traits and SCS (Table 5) were positive for midparent and REML $\mathrm{ANIM}_{\mathrm{A}}$ $\mathrm{h}_{\mathrm{WH}}^{2}$. Correlations for midparent $\mathrm{h}_{\mathrm{WH}}^{2}$ ranged from 0.41 
Table 3. Mean within-herd $\mathrm{h}^{2}$ for fat yield, protein yield, and SCS for daughter-dam and daughter-sire regressions, midparent, ${ }^{1} \mathrm{REML}_{\mathrm{SIRE}},{ }^{2} \mathrm{REML}_{\mathrm{MGS}},{ }^{3}$ and $\mathrm{REML}_{\mathrm{ANIM}}{ }^{4}$ for 45 large herds

\begin{tabular}{lllllll}
\hline & \multicolumn{5}{c}{ Within-herd $\mathrm{h}^{2}$} \\
\cline { 2 - 7 } Trait & $\begin{array}{l}\text { Daughter- } \\
\text { dam }\end{array}$ & $\begin{array}{l}\text { Daughter- } \\
\text { sire }\end{array}$ & Midparent & REML sire & $\begin{array}{l}\text { REML } \\
\text { MGS }\end{array}$ & $\begin{array}{l}\text { REML } \\
\text { animal }\end{array}$ \\
\hline Fat yield & 0.33 & 0.24 & 0.29 & 0.16 & 0.17 & 0.18 \\
Protein yield & 0.28 & 0.30 & 0.29 & 0.19 & 0.20 & 0.20 \\
SCS & 0.21 & 0.03 & 0.12 & 0.10 & 0.10 & 0.10 \\
\hline
\end{tabular}

${ }^{1}$ Mean of daughter-dam and daughter-sire $\mathrm{h}_{\mathrm{WH}}^{2}$.

${ }^{2}$ Heritability estimates derived with sire models in REML.

${ }^{3}$ Heritability estimates derived with sire-maternal grandsire models in REML.

${ }^{4}$ Heritability estimates derived with animal models in REML.

between milk yield and SCS to 0.91 between milk and protein yields. Correlations for $\mathrm{REML}_{\mathrm{ANIM}} \mathrm{h}_{\mathrm{WH}}^{2}$ tended to be smaller and ranged from 0.05 between milk yield and SCS to 0.89 between milk and protein yields. Correlations between daughter-dam and daughter-sire $\mathrm{h}_{\mathrm{WH}}^{2}$ for the same trait (not shown) also were positive and ranged from 0.23 for SCS to 0.46 for fat yield.

\section{Mean $h_{\mathrm{WH}}^{2}$ Across All Herds}

Estimates of $\mathrm{h}_{\mathrm{WH}}^{2}$ for yield traits and SCS were averaged for the 1,939 herds in the randomly selected data subsets (Table 6). Results varied minimally across subsets, so only averages across subsets are reported. Mean all-herd $h_{\mathrm{WH}}^{2}$ ranged from 0.24 (daughter-sire $\mathrm{h}_{\mathrm{WH}}^{2}$ for milk yield) to 0.40 (daughter-dam $\mathrm{h}_{\mathrm{WH}}^{2}$ for fat yield). The $\mathrm{h}_{\mathrm{WH}}^{2}$ for SCS appeared to be overestimated by the daughter-dam regression (all-herd $\mathrm{h}_{\mathrm{WH}}^{2}=0.24$ ) and underestimated by the daughter-sire regression (all-herd $\left.\mathrm{h}_{\mathrm{WH}}^{2}=0.06\right)$, but midparent $\mathrm{h}_{\mathrm{WH}}^{2}\left(\right.$ all-herd $\left.\mathrm{h}_{\mathrm{WH}}^{2}=0.14\right)$ was closer to the $\mathrm{h}^{2}$ of 0.10 assumed for national evaluations (Schutz, 1994). Daughter-dam $\mathrm{h}_{\mathrm{WH}}^{2}$ were considerably higher than daughter-sire $\mathrm{h}_{\mathrm{WH}}^{2}$ for milk and fat yields and SCS, whereas daughter-sire $\mathrm{h}_{\mathrm{WH}}^{2}$ was nearly the same for protein yield.
Treating heritability within herd as a random effect constrained $\mathrm{h}_{\mathrm{WH}}^{2}$ between 0 and 1 for milk yield and effectively regressed $h_{\mathrm{WH}}^{2}$ toward the subset average. The daughter-sire $\mathrm{h}_{\mathrm{WH}}^{2}$ was 0 for some herds in all data subsets and was as high as 0.93 , whereas the range (0.04 to 0.67 ) was smaller for daughter-dam $\mathrm{h}_{\mathrm{WH}}^{2}$. Heritability estimates generally stayed between 0 and 1 for fat and protein yields and SCS as well. Of 1,939 herds, 2 had a daughter-dam $\mathrm{h}_{\mathrm{WH}}^{2}$ of $<0$ for 1 trait and 6 herds had a daughter-sire $h_{\mathrm{WH}}^{2}$ of $>1$ for 1 trait. The $h_{\mathrm{WH}}^{2}$ estimation procedures of model 3 also resulted in heritability estimates that increasingly deviated from mean heritability as herd size increased. Variation in $\mathrm{h}_{\mathrm{WH}}^{2}$ for different herd sizes is shown in Figure 1 for daughterdam $h_{\mathrm{WH}}^{2}$. Variance for $\mathrm{h}_{\mathrm{WH}}^{2}$ and the interquartile range increased as herd size increased. Medium-sized herds (251 to 500 records) had a larger range than herds with $>1,000$ records to estimate $\mathrm{h}_{\mathrm{WH}}^{2}$, but variance was greatest for herds with $>1,000$ records available.

Variation in milk yield $\mathrm{h}_{\mathrm{WH}}^{2}$ for different herd sizes with no fixed regression on dam milk yield is displayed in Figure 2. The correlation of heritability estimates generated with and without $\mathrm{b}_{2} \mathrm{D}$ (from model [3]) was 0.75 , and the range of $h_{\mathrm{WH}}^{2}$ was greater $(-0.48$ to 1.14$)$ when $b_{2} \mathrm{D}$ was removed. Heritability estimates for

Table 4. Correlations of within-herd $\mathrm{h}^{2}$ estimated with sire models, sire-maternal grandsire (MGS) models, and animal models, with within-herd $\mathrm{h}^{2}$ estimated with daughter-dam regressions (DDam), daughter-sire regressions (DSire), and midparent average (Mid), ${ }^{1}$ for 45 large herds for milk, fat, and protein yields and SCS

\begin{tabular}{|c|c|c|c|c|c|c|c|c|c|}
\hline \multirow[b]{2}{*}{ Trait } & \multicolumn{3}{|c|}{ Sire model } & \multicolumn{3}{|c|}{ Sire-MGS model } & \multicolumn{3}{|c|}{ Animal model } \\
\hline & DDam & DSire & Mid & DDam & DSire & Mid & DDam & DSire & Mid \\
\hline Milk & 0.31 & 0.43 & 0.44 & 0.42 & 0.56 & 0.59 & 0.68 & 0.44 & 0.61 \\
\hline Fat & 0.37 & 0.58 & 0.56 & 0.51 & 0.67 & 0.69 & 0.60 & 0.52 & 0.63 \\
\hline Protein & $0.22^{*}$ & 0.33 & 0.34 & 0.43 & 0.53 & 0.57 & 0.65 & 0.43 & 0.57 \\
\hline SCS & $-0.02 *$ & $0.28 *$ & $0.09 *$ & $0.15^{*}$ & $0.27 *$ & $0.23 *$ & 0.50 & $0.22 *$ & 0.49 \\
\hline
\end{tabular}

${ }^{1}$ Mean of daughter-dam and daughter-sire $\mathrm{h}_{\mathrm{WH}}^{2}$.

*Correlation not significant $(P>0.05)$. 
Table 5. Correlations among milk, fat, and protein yields and SCS for midparent ${ }^{1}$ (above diagonal) and $\mathrm{REML}_{\mathrm{ANIM}^{2}}$ (below diagonal) within-herd $\mathrm{h}^{2}$ for 45 large herds

\begin{tabular}{lllll}
\hline Trait & $\begin{array}{l}\text { Milk } \\
\text { yield }\end{array}$ & $\begin{array}{l}\text { Fat } \\
\text { yield }\end{array}$ & $\begin{array}{l}\text { Protein } \\
\text { yield }\end{array}$ & SCS \\
\hline Milk yield & & 0.80 & 0.91 & 0.41 \\
Fat yield & 0.70 & & 0.83 & 0.47 \\
Protein yield & 0.89 & 0.64 & & 0.45 \\
SCS & 0.05 & 0.10 & 0.07 & \\
\hline
\end{tabular}

${ }^{1}$ Mean of daughter-dam and daughter-sire $\mathrm{h}_{\mathrm{WH}}^{2}$.

${ }^{2}$ Heritability estimates derived with animal models in REML.

larger herds were similar with and without fixed regressions, but heritability was more variable for small herds. Heritability estimates were less than 0 for $15 \%$ of herds when $b_{2} D$ was removed. Heritability estimates for $3 \%$ of herds without $\mathrm{b}_{3} \mathrm{~S}$ (from model [3]) and $0.5 \%$ herds without $\mathrm{b}_{4}\left(\mathrm{Sb} \times \mathrm{SD}_{\mathrm{k}}\right)$ were greater than 1 . Removal of $\mathrm{b}_{4}\left(\mathrm{~S} \times \mathrm{SD}_{\mathrm{k}}\right)$ deflated $\mathrm{h}_{\mathrm{WH}}^{2}$ for small herds with high phenotypic variance. Because $b_{2 l} G_{l}$ is treated as a random effect, the coefficient for small herds was regressed toward the subset average more severely than were coefficients for larger herds. This created a genetic SD estimate that is only marginally higher than the subset mean genetic SD. When combined with a
Table 6. Mean within-herd $\mathrm{h}^{2}$ for milk, fat, and protein yields and SCS estimated with daughter-dam and daughter-sire regressions for 1,939 herds

\begin{tabular}{lll}
\hline & \multicolumn{2}{c}{ Within-herd $\mathrm{h}^{2}$} \\
\cline { 2 - 3 } Trait & $\begin{array}{l}\text { Daughter-dam } \\
\text { regression }\end{array}$ & $\begin{array}{l}\text { Daughter-sire } \\
\text { regression }\end{array}$ \\
\hline Milk yield & 0.35 & 0.24 \\
Fat yield & 0.40 & 0.29 \\
Protein yield & 0.31 & 0.32 \\
SCS & 0.24 & 0.06 \\
\hline
\end{tabular}

high phenotypic variance estimate, the result is an underestimated $h_{\mathrm{WH}}^{2}$. The reverse is true for small herds with low phenotypic variance, and the effect was a correlation of -0.45 between daughter-sire $h_{W H}^{2}$ herd genetic SD without the interaction of $\mathrm{b}_{4}\left(\mathrm{~S} \times \mathrm{SD}_{\mathrm{k}}\right)$ for milk yield, compared with 0.54 with the interaction.

Correlations between daughter-dam and daughtersire $\mathrm{h}_{\mathrm{WH}}^{2}$ for each trait are shown in Table 7, as well as daughter-dam and daughter-sire correlations among traits. Correlations between daughter-dam and daughter-sire $h_{\mathrm{WH}}^{2}$ ranged from 0.05 for milk yield to 0.13 for fat yield. For daughter-dam $\mathrm{h}_{\mathrm{WH}}^{2}$, the correlation between SCS and milk yield was 0.08 compared with a

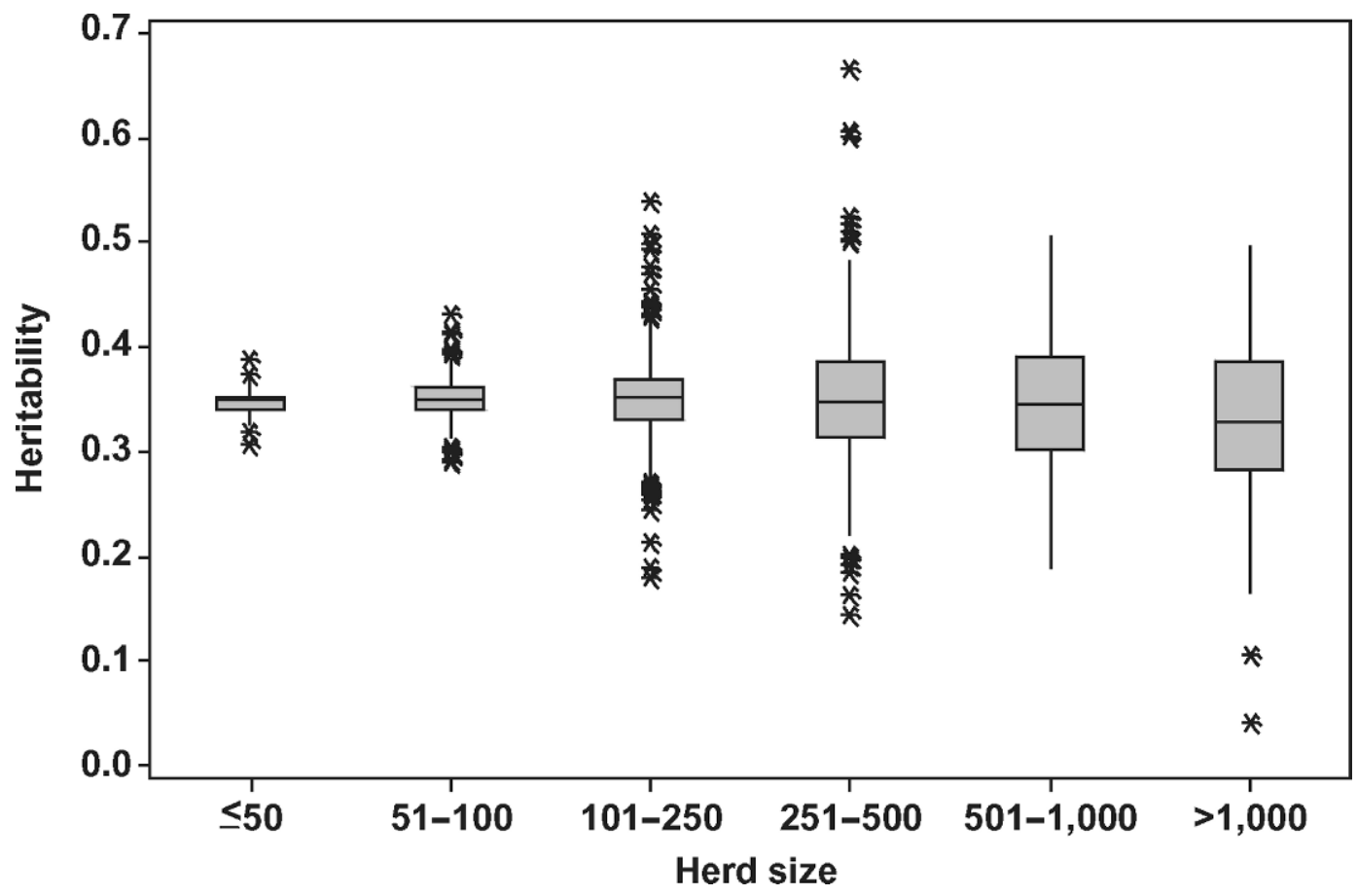

Figure 1. Box plot of daughter-dam $\mathrm{h}^{2}$ estimates for milk yield by the total number of lactation records per herd (herd size) used to estimate $\mathrm{h}_{\mathrm{WH}}^{2}$. Median values are represented by the horizontal center line, the top and bottom of the shaded boxes represent the interquartile range, the vertical bars represent extreme values that are within 1.5 times the interquartile range, and the asterisks represent extreme values outside that range. 


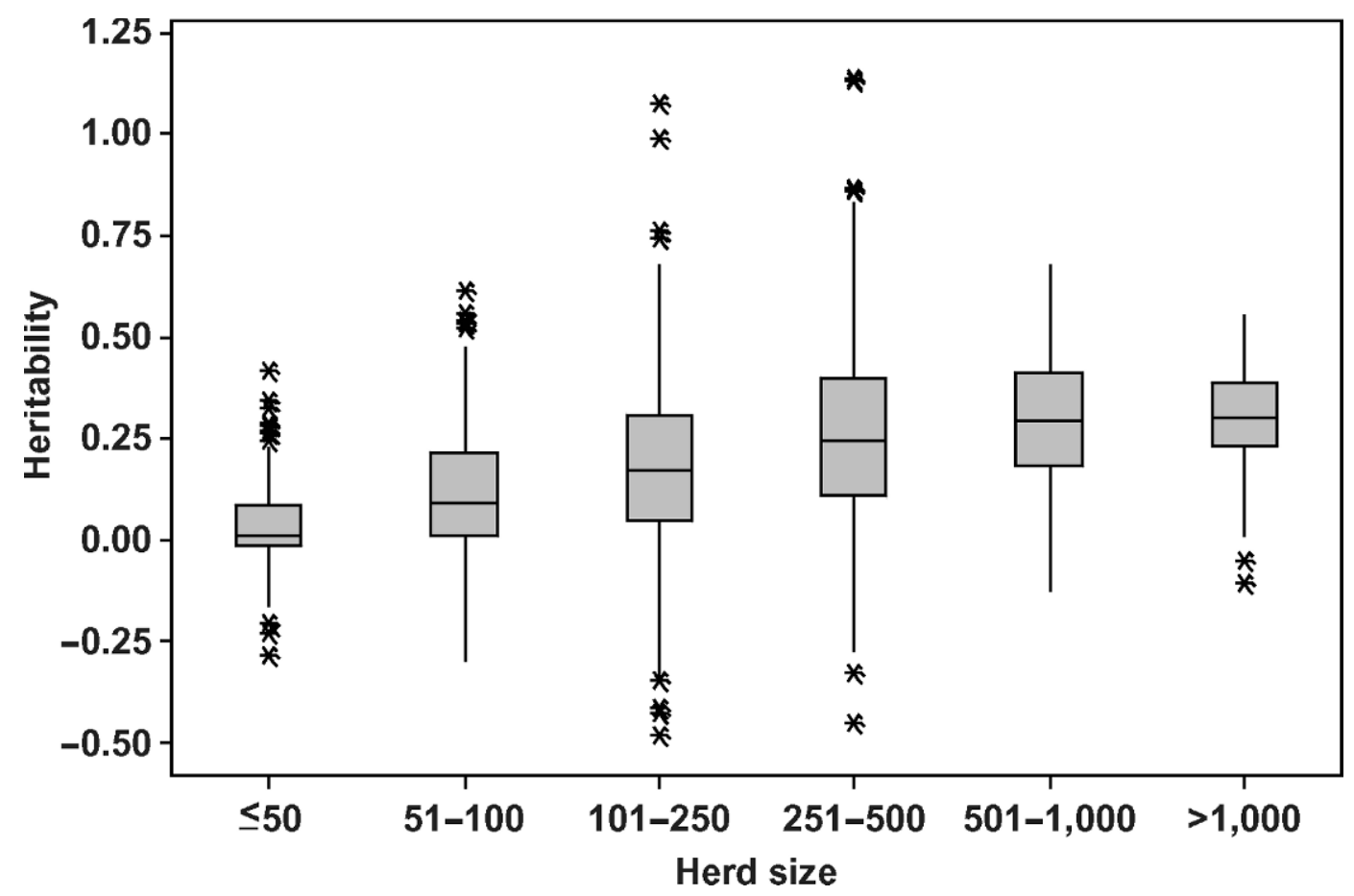

Figure 2. Box plot of daughter-dam $h^{2}$ estimates with no fixed regression coefficient for milk yield by the total number of lactation records per herd (herd size) used to estimate $\mathrm{h}_{\mathrm{WH}}^{2}$. Median values are represented by the horizontal center line, the top and bottom of the shaded boxes represent the interquartile range, the vertical bars represent extreme values that are within 1.5 times the interquartile range, and the asterisks represent extreme values outside that range.

correlation of 0.81 between milk and protein yields. Correlations were similar for daughter-sire $\mathrm{h}_{\mathrm{WH}}^{2}$ and ranged from 0.02 between milk yield and SCS to 0.75 between milk and protein yields.

\section{Data Adjustments}

The ratios of observed genetic variance to assumed true genetic variance for milk, fat, and protein yield and SCS are given in Table 8. Low ratios are preferred, and ratios greater than 1.0 indicate that more fluctuation was observed than expected. The EBV were pooled across subsets to generate a sufficient sample size. Ratios were based on EBV for 64 sires for milk, fat, and

Table 7. Correlations between daughter-dam and daughter-sire $\mathrm{h}^{2}$ (diagonal) and correlations among daughter-dam $\mathrm{h}^{2}$ (above diagonal) and among daughter-sire $\mathrm{h}^{2}$ (below diagonal) for yield traits and SCS for 1,939 herds

\begin{tabular}{lllll}
\hline Trait & $\begin{array}{l}\text { Milk } \\
\text { yield }\end{array}$ & $\begin{array}{l}\text { Fat } \\
\text { yield }\end{array}$ & $\begin{array}{l}\text { Protein } \\
\text { yield }\end{array}$ & SCS \\
\hline Milk yield & 0.05 & 0.51 & 0.81 & 0.08 \\
Fat yield & 0.46 & 0.13 & 0.59 & 0.14 \\
Protein yield & 0.75 & 0.55 & 0.08 & 0.08 \\
SCS & 0.02 & 0.10 & 0.06 & 0.07 \\
\hline
\end{tabular}

protein yield, and 59 sires for SCS. The effect of adjusting for $\mathrm{h}_{\mathrm{WH}}^{2}$ on observed genetic variance was inconsistent across traits. Observed genetic variance was inflated for milk yield when no adjustment was made

Table 8. Ratio of genetic variance estimated from fluctuations in subsequent genetic evaluations to assumed true genetic variance $\left(\hat{\sigma}_{a}^{2} / \sigma_{a}^{2}\right)$ and the regression (b) of subsequent breeding values on previous breeding values before and after adjustment for within-herd $h^{2}$ from daughter-dam and daughter-sire regressions, and midparent ${ }^{1}$

\begin{tabular}{lllll}
\hline & \multicolumn{4}{c}{ Within-herd $\mathrm{h}^{2}$ adjustment } \\
\cline { 2 - 5 } Trait & None & $\begin{array}{l}\text { Daughter- } \\
\text { dam }\end{array}$ & $\begin{array}{l}\text { Daughter- } \\
\text { sire }\end{array}$ & Midparent \\
\hline & \multicolumn{4}{c}{$\left(\hat{\sigma}_{a}^{2} / \sigma_{a}^{2}\right)$} \\
Milk yield & 1.29 & $1.13^{*}$ & 1.16 & $1.12^{*}$ \\
Fat yield & 1.10 & 1.09 & 1.13 & 1.09 \\
Protein yield & 1.11 & 1.22 & 1.21 & 1.19 \\
SCS & 0.92 & 0.99 & 0.80 & 1.06 \\
& & & $(\mathrm{~b})$ & 0.83 \\
Milk yield & 0.84 & 0.78 & 0.90 & 0.82 \\
Fat yield & 0.81 & 0.77 & 0.90 & 0.88 \\
Protein yield & 0.88 & 0.85 & 0.90 & 0.69 \\
SCS & 0.75 & 0.55 & 0.79 & \\
\hline
\end{tabular}

${ }^{1}$ Mean of daughter-dam and daughter-sire $\mathrm{h}_{\mathrm{WH}}^{2}$.

$* \hat{\sigma}_{a}^{2}$ before and after data adjustments different at $P<0.05$. 
Table 9. Type III mean square estimates $\left(\hat{\sigma}^{2}\right)$, values for herds in the 10th and 90th percentiles, and predicted change in within-herd heritability $\left(\Delta \mathrm{h}_{\mathrm{WH}}^{2}\right)$ from the 10th to 90 th percentile for the following independent variables: herd-standard deviation of mature-equivalent milk yield (milk SD), region (California, Northeast, Southeast, Wisconsin), average number of first-lactation animals calving per year (heifers, n) nested within region, herd average mature-equivalent milk yield (milk average), percentage of cows identified by a registration number $\left(\mathrm{PCT}_{\mathrm{HOL}}\right)$, and average age at first calving ${ }^{1}$

\begin{tabular}{|c|c|c|c|c|}
\hline \multirow[b]{2}{*}{ Independent variable } & \multirow[b]{2}{*}{$\hat{\sigma}^{2}$} & \multicolumn{2}{|c|}{ Percentile } & \multirow{2}{*}{$\underset{\%}{\Delta \mathrm{h}_{\mathrm{WH}}^{2},}$} \\
\hline & & 10 & 90 & \\
\hline Milk SD & 0.231 & $1,158 \mathrm{~kg}$ & $1,824 \mathrm{~kg}$ & 4.5 \\
\hline Heifers, n (California) & $0.023^{2}$ & 22 & 368 & -3.9 \\
\hline Heifers, $\mathrm{n}$ (Northeast) & $0.023^{2}$ & 9 & 63 & 2.6 \\
\hline Heifers, n (Southeast) & $0.023^{2}$ & 16 & 99 & 0.0 \\
\hline Heifers, n (Wisconsin) & $0.023^{2}$ & 9 & 38 & -0.5 \\
\hline Milk average & $0.019^{2}$ & $9,759 \mathrm{~kg}$ & $12,750 \mathrm{~kg}$ & 1.3 \\
\hline $\mathrm{PCT}_{\mathrm{HOL}}{ }^{3}$ & $0.011^{2}$ & $0 \%$ & $100 \%$ & 1.3 \\
\hline First calving age & $0.010^{2}$ & $24.6 \mathrm{mo}$ & $28.9 \mathrm{mo}$ & -0.9 \\
\hline California & $0.006^{4}$ & & & $26^{5}$ \\
\hline Northeast & $0.006^{4}$ & & & $31^{5}$ \\
\hline Southeast & $0.006^{4}$ & & & $29^{5}$ \\
\hline Wisconsin & $0.006^{4}$ & & & $29^{5}$ \\
\hline
\end{tabular}

${ }^{1}$ All effects are significant $(P<0.05)$.

${ }^{2} \hat{\sigma}^{2}$ associated with numbers of first-lactation heifers per year within region.

${ }^{3}$ Results based on linear and quadratic regression coefficients.

${ }^{4} \hat{\sigma}^{2}$ associated with region.

${ }^{5}$ Least squares mean midparent $\mathrm{h}_{\mathrm{WH}}^{2}$ for the corresponding region.

for $\mathrm{h}_{\mathrm{WH}}^{2}$ and was significantly less after adjusting for daughter-dam $(P=0.04)$ and midparent $(P=0.02)$ $\hat{\sigma}_{W H}^{2}$. There was little impact on fluctuations in EBV for fat yield and fluctuations increased after adjusting for $\mathrm{h}_{\mathrm{WH}}^{2}$ for protein yield, but not significantly $(P>0.05)$. Fluctuations for SCS were generally less than expected except with midparent $\mathrm{h}_{\mathrm{WH}}^{2}$ adjustments.

Coefficients for the regression of EBV2004 on EBV2000 are also displayed in Table 8. Regression coefficients were less than 1.0 in all cases, indicating some level of bias in the evaluations even when adjusted for $\mathrm{h}_{\mathrm{WH}}^{2}$. Adjusting for daughter-sire $\mathrm{h}_{\mathrm{WH}}^{2}$ indicated the least bias in evaluations. Adjusting for daughter-dam $\mathrm{h}_{\mathrm{WH}}^{2}$ decreased regression coefficients for all traits compared with no data adjustment. Significance tests are not provided for regression coefficients because of the inability to obtain the error variance of regression coefficients (Reverter et al., 1994).

The relationships between herd factors and midparent $\mathrm{h}_{\mathrm{WH}}^{2}$ are shown in Table 9. All factors were significant $(P<0.05)$ and are arranged in order of the factor associated the largest proportion of variance based on type III mean square estimates (SD of milk yield) to lowest variance (region). The variance for percentage of cows identified with a registration number is based on linear + quadratic regression coefficients. Regression coefficients indicate that greater herd phenotypic SD, higher average milk yields, a higher percentage of registered cows, and an earlier age at first calving are associated with higher $\mathrm{h}_{\mathrm{WH}}^{2}$. Midparent and daughter-sire $\mathrm{h}_{\mathrm{WH}}^{2}$ were lower from herds in California, and larger herd size (represented by more first-lactation cows) was associated with lower $\mathrm{h}_{\mathrm{WH}}^{2}$ in California. Daughterdam $h_{W H}^{2}$ tended to be less strongly related to herd SD and herd average, and more strongly related to the percentage of registered cows than were midparent or daughter-sire $\mathrm{h}_{\mathrm{WH}}^{2}$. Trends for fat yield, protein yield, and SCS were similar, except that herd average SCS was not significantly associated with $\mathrm{h}_{\mathrm{WH}}^{2}$.

\section{DISCUSSION}

A heritability estimated with daughter-dam regression for 400 daughter-dam pairs would have a standard error of approximately 0.10 (Falconer and Mackay, 1996). Therefore, accurate heritability estimates are difficult to obtain for a large proportion of US dairy herds, and methods that constrain $\mathrm{h}_{\mathrm{WH}}^{2}$ for smaller herds and allow $\mathrm{h}_{\mathrm{WH}}^{2}$ to deviate for larger herds would be preferred. Generating $\mathrm{h}_{\mathrm{WH}}^{2}$ with no fixed regression coefficients resulted in a significant increase in the number of herds with heritability estimates greater than 1 or less than 0 . However, methods with fixed regression coefficients successfully constrained $\mathrm{h}_{\mathrm{WH}}^{2}$ for small herds while allowing $\mathrm{h}_{\mathrm{WH}}^{2}$ from large herds to deviate from sample means. Including sire PTA and herd SD interactions was necessary to derive genetic variance estimates from daughter-sire regression. Including an interaction between sire PTA and herd SD assumes that a genotype-environment interaction exists and that the response to selection will be less in herds with low phenotypic variance. Reduced selection response in herds with low phenotypic variances has been documented (Kearney et al., 2004). The genetic variance estimate will still be accurate, provided there is minimal reranking of bulls across environments. Within-herd $\mathrm{h}^{2}$ was regressed toward the subset mean in the current study, whereas $\mathrm{h}_{\mathrm{WH}}^{2}$ is indirectly regressed toward regional averages (by regressing herd phenotypic SD toward the regional phenotypic SD average) in the current procedures for national genetic evaluations in the United States (Wiggans and VanRaden, 1991).

Within-herd $\mathrm{h}^{2}$ could be regressed toward herd parameters that influence $h_{\mathrm{WH}}^{2}$. Herd average and SD, region of the country or state, percentage of registered cows, herd size, and average age at first calving were all significantly associated with $\mathrm{h}_{\mathrm{WH}}^{2}$. Herds with 
greater phenotypic variance had higher heritability, which is consistent with other studies (Van Tassell et al., 1999). The heritability of yield has previously been estimated to be lower in California than in New York or Wisconsin, and heritability estimates are higher when estimated with registered daughters (Carabaño et al., 1990; Dimov et al., 1995). Larger herd size was associated with reduced heritability in some regions, which is consistent with results from Zwald et al. (2003). Although these herd parameters give some indication of $\mathrm{h}_{\mathrm{WH}}^{2}$, the total variance explained by the multiple regression model was $31 \%\left(R^{2}=0.31\right)$, indicating that the majority of variance in $\mathrm{h}_{\mathrm{WH}}^{2}$ was not accounted for by the factors analyzed.

Daughter-dam $\mathrm{h}_{\mathrm{WH}}^{2}$ generally were higher than daughter-sire $h_{\mathrm{WH}}^{2}$. For SCS, daughter-dam $\mathrm{h}_{\mathrm{WH}}^{2}$ were approximately twice as high (0.24) as the parameters used for national genetic evaluations (Schutz, 1994) and 4 times greater than daughter-sire $\mathrm{h}_{\mathrm{WH}}^{2}$. Daughterdam $h_{\mathrm{WH}}^{2}$ for milk yield were higher than previously reported heritability estimates from paternal half-sibling correlations (Van Vleck and Bradford, 1965; Van Vleck and Bradford, 1966). Environmental effects common to daughters and dams likely inflate daughterdam $\mathrm{h}_{\mathrm{WH}}^{2}$, as would any maternal or cytoplasmic effects (Van Vleck and Bradford, 1965). The relative ranking among herds for daughter-dam $\mathrm{h}_{\mathrm{WH}}^{2}$ would be accurate if common environmental and maternal effects were similar across herds.

Lower daughter-sire $\mathrm{h}_{\mathrm{WH}}^{2}$ could also indicate that sire misidentification is more common than dam misidentification. Sire misidentification would have a minimal impact on daughter-dam $\mathrm{h}_{\mathrm{WH}}^{2}$, and presumably influence $h_{\mathrm{WH}}^{2}$ from $\mathrm{REML}_{\mathrm{SIRE}}$ and REML $\mathrm{MGS}_{\mathrm{MS}}$ more severely than $\mathrm{REML}_{\mathrm{ANIM}}$. Daughter-dam $\mathrm{h}_{\mathrm{WH}}^{2}$ was not as strongly correlated with $\mathrm{h}_{\mathrm{WH}}^{2}$ generated from REML $\mathrm{SIRE}_{\mathrm{SIR}}$ and $R E M L_{M G S}$. Conversely, daughter-sire $h_{\mathrm{WH}}^{2}$ was more strongly correlated with $\mathrm{h}_{\mathrm{WH}}^{2}$ generated by REML $_{M G S}$ than $h_{\mathrm{WH}}^{2}$ generated with REML $\mathrm{ANIM}_{\text {. }}$

Because of an interaction between genotype and environment, daughter-sire $\mathrm{h}_{\mathrm{WH}}^{2}$ would be biased downward more severely than would daughter-dam $\mathrm{h}_{\mathrm{WH}}^{2}$. Both dam and daughter were required to be from the same herd, which would limit the effect of a genotype-environment interaction on $\mathrm{h}_{\mathrm{WH}}^{2}$ estimates. Sire PTA are generated across herds, and regression on sire PTA would be depressed if a genotype-environment interaction existed. Variance of the sire-herd interaction can be combined with additive genetic variance to estimate mean $\mathrm{h}_{\mathrm{WH}}^{2}$ across herds (Notter et al., 1992). The herdsire interaction was estimated to be approximately $2 \%$ of phenotypic variance for milk yield in Holsteins (Dimov et al., 1995), which indicates that daughter-sire $\mathrm{h}_{\mathrm{WH}}^{2}$ could be appreciably depressed by the presence of a genotype-environment interaction.

The effect of data adjustment on EBV fluctuations was inconsistent and only daughter-sire $\mathrm{h}_{\mathrm{WH}}^{2}$ adjustments increased regression coefficients of EBV2004 on EBV2000. Some possible negative impacts of adjusting for $\mathrm{h}_{\mathrm{WH}}^{2}$ should be considered. Daughter-dam regression could expand the influence of preferential treatment. Preferential treatment within certain cow families is likely to increase daughter-dam $\mathrm{h}_{\mathrm{WH}}^{2}$, and genetic evaluations that adjust for daughter-dam $\mathrm{h}_{\mathrm{WH}}^{2}$ would weight those records even more heavily. In addition, the method used to generate daughter-sire $\mathrm{h}_{\mathrm{WH}}^{2}$ has part-whole influences. Records are weighted more heavily in herds in which daughter yield is highly correlated with past sire evaluations, which could create a stronger relationship between daughter performance and sire evaluations in future evaluations and inflate future daughter-sire $h_{\mathrm{WH}}^{2}$. Alternative uses for $h_{\mathrm{WH}}^{2}$ might avoid such issues and should be investigated. Reliability could be adjusted to reflect the impact of $\mathrm{h}_{\mathrm{WH}}^{2}$. Progeny-test herds with low $\mathrm{h}_{\mathrm{WH}}^{2}$ may be candidates for DNA parentage verification or removal from progeny-test programs.

\section{CONCLUSIONS}

Estimates for $\mathrm{h}_{\mathrm{WH}}^{2}$ can be generated using the regression of daughter records on dam records and the regression of daughter records on sire PTA with moderate accuracy. Daughter-dam $\mathrm{h}_{\mathrm{WH}}^{2}$ were a stronger indicator of heritability estimated with an animal model, whereas daughter-sire $h_{\mathrm{WH}}^{2}$ were stronger indicators of heritability estimated with sire and sire-MGS models. Both daughter-dam and daughter-sire methods demonstrate that significant differences exist among herds for heritability. Those differences could result from variability in recordkeeping (especially more accurate pedigrees), genotype-environment interaction, or other identifiable herd factors, including the percentage of registered cows, herd size, herd average yield or SCS, herd standard deviations for yield and SCS, average age at first calving, and region of the country. Heritability differences among herds could substantially alter the accuracy of EBV depending on the average $\mathrm{h}_{\mathrm{WH}}^{2}$ of the herds in which a bull's daughters are located.

Data adjustments generally did not reduce fluctuations in subsequent genetic evaluations and only daughter-sire $\mathrm{h}_{\mathrm{WH}}^{2}$ improved regressions of subsequent EBV. For the methods that were investigated, the effect 
of preferential treatment on $\mathrm{h}_{\mathrm{WH}}^{2}$ is not clear, or whether part-whole influences from past genetic evaluations would artificially inflate $\mathrm{h}_{\mathrm{WH}}^{2}$ for some herds. Other methods of incorporating $\mathrm{h}_{\mathrm{WH}}^{2}$ into genetic evaluations, such as adjusting reliability estimates based on $\mathrm{h}_{\mathrm{WH}}^{2}$, that would avoid effects of preferential treatment and part-whole relationships should be investigated.

\section{ACKNOWLEDGMENTS}

The authors appreciate funding from the Agricultural Research Service, USDA. The cooperation of AgriTech Analytics (Visalia, CA), AgSource Cooperative Services (Verona, WI), Dairy Records Management Systems (Raleigh, NC), DHI Computing Services (Provo, UT), and Texas DHIA (College Station, TX) in supplying yield data through the National Genetic Improvement Program was invaluable. The assistance of S. M. Hubbard, Animal Improvement Programs Laboratory (Beltsville, $\mathrm{MD}$ ), and 2 anonymous reviewers in manuscript preparation is appreciated.

\section{REFERENCES}

Banos, G., G. R. Wiggans, and R. L. Powell. 2001. Impact of paternity errors in cow identification on genetic evaluations and international comparisons. J. Dairy Sci. 84:2523-2529.

Carabaño, M. J., K. M. Wade, and L. D. Van Vleck. 1990. Genotype by environment interactions for milk and fat production across regions of the United States. J. Dairy Sci. 73:173-180.

Dimov, G., L. G. Albuquerque, J. F. Keown, L. D. Van Vleck, and H. D. Norman. 1995. Variance of interaction effects of sire and herd for yield traits of Holsteins in California, New York, and Pennsylvania with an animal model. J. Dairy Sci. 78:939-946.

Falconer, D. S., and T. F. C. Mackay. 1996. Introduction to Quantitative Genetics. 4th ed. Longman Group, Essex, UK.

Gelderman, H., U. Pieper, and W. E. Weber. 1986. Effect of misidentification on the estimation of breeding value and heritability in cattle. J. Anim. Sci. 63:1759-1768.
Gilmour, A. R., B. J. Gogel, B. R. Cullis, S. J. Welham, and R. Thompson. 2002. AS-REML User Guide. Release 1.0. VSN International, Hemel Hempstead, UK.

Kearney, J. F., M. M. Schutz, P. J. Boettcher, and K. A. Weigel. 2004. Genotype $\times$ environment interaction for grazing versus confinement. I. Production traits. J. Dairy Sci. 87:501-509.

Lofgren, D. L., W. E. Vinson, and R. E. Pearson. 1985. Heritability of milk yield at different herd means and variances for production. J. Dairy Sci. 68:2737-2739.

Misztal, I. 2004. BLUPF90-A flexible mixed model program in Fortran 90. http://nce.ads.uga.edu/ ignacy/numpub/blupf90/docs/ blupf90.pdf Accessed Dec. 22, 2005.

Notter, D. R., B. Tier, and K. Meyer. 1992. Sire $\times$ herd interactions for weaning weight in beef cattle. J. Anim. Sci. 70:2359-2365.

Powell, R. L., G. R. Wiggans, and H. D. Norman. 1994. Effect of sampling status and adjustment for heterogeneous variance on bias in bull evaluations. J. Dairy Sci. 77:883-890.

Reverter, A., B. L. Golden, R. M. Bourdon, and J. S. Brinks. 1994. Technical note: Detection of bias in genetic predictions. J. Anim. Sci. 72:34-37.

SAS Institute. 2000. SAS/STAT User's Guide, Version 8. SAS Institute, Cary, NC.

Schutz, M. M. 1994. Genetic evaluation of somatic cell scores for United States dairy cattle. J. Dairy Sci. 77:2113-2129.

van der Werf, J. H. J., T. H. E. Meuwissen, and G. De Jong. 1994. Effects of correction for heterogeneity of variance on bias and accuracy of breeding value estimation for Dutch dairy cattle. J. Dairy Sci. 77:3174-3184.

Van Tassell, C. P., G. R. Wiggans, and H. D. Norman. 1999. Method $\mathrm{R}$ estimates of heritability for milk, fat, and protein yields of United States dairy cattle. J. Dairy Sci. 82:2231-2237.

Van Vleck, L. D., and G. E. Bradford. 1965. Comparison of heritability estimates from daughter-dam regression and paternal half-sib correlation. J. Dairy Sci. 48:1372-1375.

Van Vleck, L. D., and G. E. Bradford. 1966. Genetic and maternal influence on the first three lactations of Holstein cows. J. Dairy Sci. 49:45-52.

Vinson, W. E. 1987. Potential bias in genetic evaluations from differences in variation within herds. J. Dairy Sci. 70:2450-2455.

Weigel, K. A., and T. J. Lawlor. 1994. Adjustment for heterogeneous variance in genetic evaluations for conformation of United States Holsteins. J. Dairy Sci. 77:1691-1701.

Wiggans, G. R., and P. M. VanRaden. 1991. Method and effect of adjustment for heterogeneous variance. J. Dairy Sci. 74:43504357.

Zwald, N. R., K. A. Weigel, W. F. Fikse, and R. Rekaya. 2003. Identification of factors that cause genotype by environment interaction between herds of Holstein cattle in seventeen countries. J. Dairy Sci. 86:1009-1018. 